Rev. Biol. Trop., 47(1-2): 263-269, 1999

www.ucr.ac.cr www.ots.ac.cr www.ots.duke.edu

\title{
Late dry season habitat use of common opossum, Didelphis marsupialis (Marsupialia: Didelphidae) in neotropical lower montane agricultural areas
}

\author{
Christopher S. Vaughan 1,2 and L. Foster Hawkins ${ }^{2}$ \\ 1 Regional Wildlife Management Program, Universidad Nacional, Heredia, Costa Rica. Present address: Institute for \\ Environmental Studies, University of Wisconsin, Madison, WI 53705, USA; fax: (608)-262-0014, e-mail: cvaughan- \\ @ facstaff.wisc.edu \\ 2 Associated Colleges of the Midwest, San Pedro de M. O., San José, Costa Rica.
}

Received 29-I-1998. Corrected 5-XI-1998. Accepted 13-XI-1998

\begin{abstract}
Three Didelphis marsupialis were radio tracked during late dry season (23 February-26 April, 1983) in agricultural area at $1500 \mathrm{~m}$ elevation in Central Valley, Costa Rica. All animals were nocturnally active, significantly more so between $2100-0300 \mathrm{~h}$. Fifty diurnal den site locations were found, $96 \%$ inside tree cavities in living fence rows or abandoned squirrel nests in windbreaks. Two females occupied 3.4 and 3.1 ha $95 \%$ home ranges, moving an average 890 and $686 \mathrm{~m}$ nightly respectively. The male occupied a 5.6 ha $95 \%$ home range for 42 days overlapping $90 \%$ of females' home ranges. Over the next 15 days, he moved $1020 \mathrm{~m}$ south, establishing three temporary home ranges. During nocturnal movements, windbreaks and living fence rows were used in higher proportion than available, while pasture, roads and cultivated lands were used less then available within $100 \%$ home ranges. Abandoned coffee and spruce plantations, fruit orchards and overgrown pastures were used in equal proportions to availability in 100\% home ranges. Opossum conservation techniques in coffee growing areas include promoting spruce windbreaks, living fence rows, and garbage dumps.
\end{abstract}

Key words: Costa Rica, Didelphis marsupialis, habitat use, home range, living fence rows, dens, radio-telemetry, windbreaks.

How animals use space is important for understanding their social structure, foraging strategy, population dynamics and genetic structure (Brown and Orians 1970). Dry seasons in tropical countries can be stressful periods of limited food and water for wildlife species (Knight et al. 1988). The genus Didelphis is the most widely distributed marsupial genus worldwide and its three members range from southern Canada to central Argentina (Austad 1988, Gardner 1982, O’Connell 1979). Most research on the Didelphis genus has been done on the Virginia opossum (D. virginiana) in the United States (see Gardner 1982 for a review); although a few studies exist on its congenitors, D. albiventris and $D$. marsupialis (Sunquist et al. 1987, TyndaleBiscoe and MacKenzie 1976) in South America. The present is the first ecological study on any Didelphis species in Central America. Its objectives were to characterize the D. marsupialis activity, movement and use of a lower montane agricultural area in Costa Rica during the late dry season. 


\section{METHODS}

Study site: The study area $\left(10^{\circ} 02^{\prime} \mathrm{N}\right.$, $84^{\circ} 55^{\prime} \mathrm{W}$ ) was about 25 hectares in size, 1550 $\mathrm{m}$ in elevation and located one $\mathrm{km}$ northwest of the village of Concepción de San Rafael de Heredia, Heredia Province, Costa Rica and about $25 \mathrm{~km}$ north of San Jose, Costa Rica (Fig. 1). The four farms comprising the study area were found in the lower montane moist forest life zone (Tosi 1969). Mean annual rainfall was $2132 \mathrm{~mm}$ (Anonymous 1975) with over $80 \%$ falling in the wet season (May to December). Major cover types in the study area included: a) pastures grazed by cattle, b) five-year old tree plantations of spruce ( $\mathrm{Cu}$ pressus lusitanica) and alder (Alnus jornalensis) and fruit orchards (Citrus sp., Persea sp., ) with understories of abandoned fields, and c) abandoned coffee plantations with a 7-m over story of Inga sp. These cover types were normally separated by: a) spruce windbreaks about $20 \mathrm{~m}$ tall and 5-15 $\mathrm{m}$ wide, and b) living fencerows made up of species, such as Ficus sp., Erythrina sp, Rapanea sp,, Rhamnus capraefolia, Viburnum costaricanus, Cithaexylum donnell-smithii, and Croton sp. of different ages and sizes (3-5 $\mathrm{m}$ tall, 2-7 $\mathrm{m}$ wide)(A. Chaverri, pers. comm.). There was one unpaved road with living fence rows on either side, seven houses and three domestic garbage pits in the study area (Fig. 1).

Capture: The study was conducted between February 21 and April 26, 1983. Opossums were captured between 21-23 February using \#2 National traps baited with ripe bananas. Each animal was measured, weighed and fitted

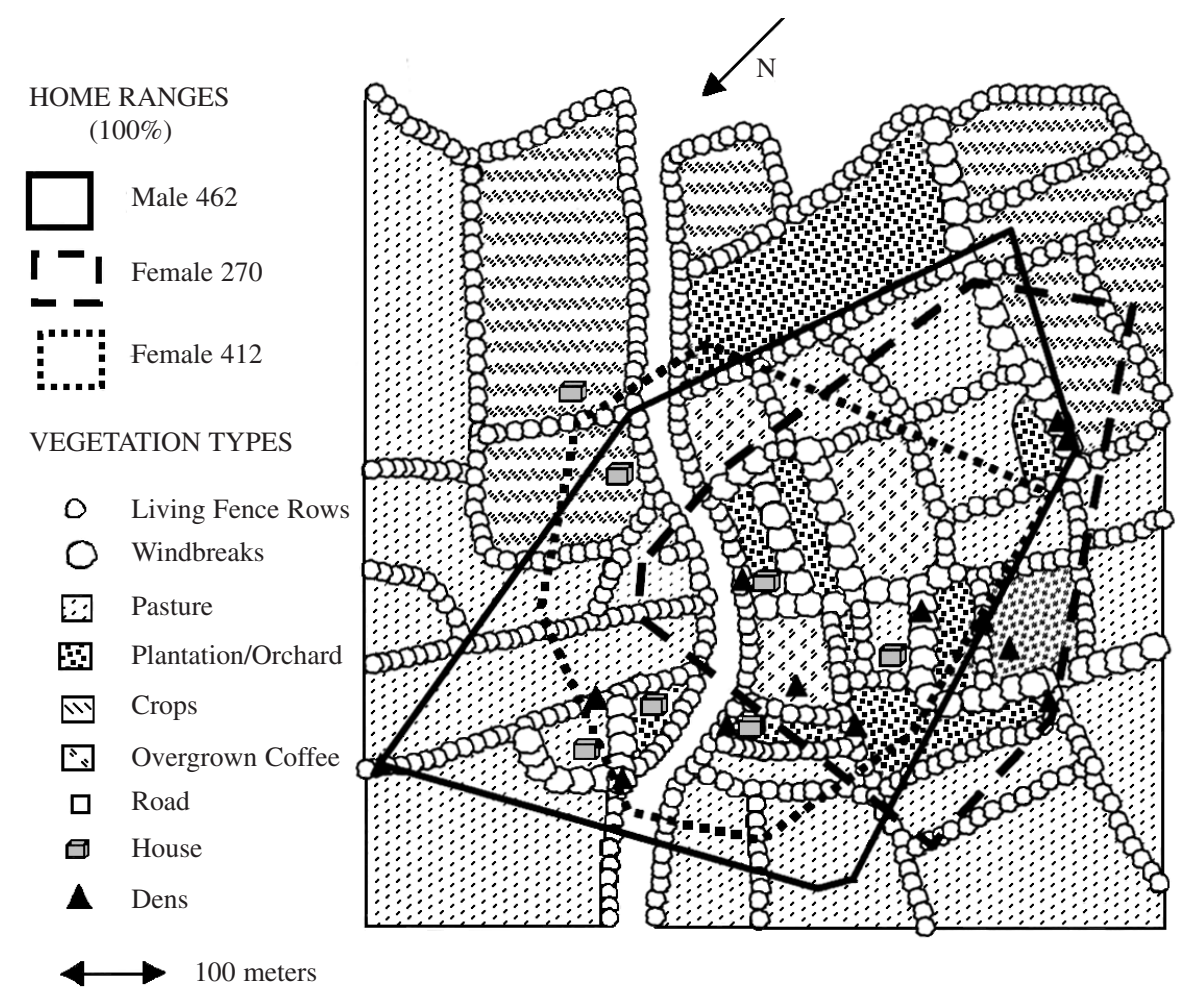

Fig. 1. Home ranges (100\%) and vegetation types, Concepción de San Rafael de Heredia, Costa Rica 
with a radio-telemetry collar and released at the capture site within four hours of capture; tracking began two days later to allow recovery. Radio collars weighed 16 gm and consisted of: a) an SM1 transmitter (AVM Instrument Company, Dublin, CA), b) two 1.75 volt alkaline batteries connected in parallel and c) an external $30 \mathrm{~cm}$ guitar string antenna. Electrical components were thinly coated with paraffinbeeswax mixture covered with dental acrylic. Collars were made of plastic tubing, wrapped with colored tape to aid opossum identification. Numbers for each individual corresponded to their radio frequency.

Radio telemetry: Preliminary 24-h tracking showed the animals were nocturnal, thus data was taken from 1800 to 0500 at 30-min intervals. Radio telemetry localizations utilized a compass, LA12 receiver and Yagi antenna (AVM Instrument Company, Dublin, CA). For radio-tracking, 20 telemetry tracking stations were marked on a hillside $150 \mathrm{~m}$ east of the animals home ranges and plotted on an aerial photograph $(1: 1,000,1977$, Instituto Geográfico Nacional, San José, Costa Rica). A two-degree telemetry reading error was estimated after placing radio collars in known locations and calculating differences between these and estimated angles from telemetry stations. Data was collected at 30-minute intervals by obtaining the strongest signal from each of two telemetry stations, lining up a compass on this signal and triangulating the angles from the two stations using a protractor. Two to five minutes elapsed between readings.

Animal activity: Activity was determined by listening to 20 -second pulse signals from the first fixed location each 30 min. "Inactive" fixes did not vary in volume over time and "active" fixes were irregular pulses of variable intensity. Data was analyzed by comparing activity between four, three-hour blocks with a contingency table. Distance moved nightly was estimated by summing linear distances between consecutive 30 or $60 \mathrm{~min}$ locations taken from 1800-0600 hs.
Home ranges were determined by the minimum convex polygon method (Hayne 1949, Mohr 1947). All observations (100\% home range) frequently included areas where no animals were observed, so $95 \%$ home ranges were calculated for each animal to eliminate unused home range edges. Five percent of total observations for each study animal were removed in a step-wise manner by eliminating those points which resulted in the greatest area reduction.

To analyze habitat use in proportion to its availability, gross cover type was classified using the earlier mentioned aerial photographs (1:1000) and ground surveys. Percent of each cover type available in combined opossum's $95 \%$ and $100 \%$ home ranges were determined by overlaying a grid (16 dots/.25"2 ) on the cover map, counting points found in each cover type and converting these to percentages. Percent use of cover type for combined $95 \%$ and $100 \%$ opossums home ranges was determined by summing all telemetry locations for non-den locations in each and converting these to percentages. The habitat use index (Dhb) determined cover preferences with the formula, Dhb $=\mathrm{r}$ $\mathrm{p} /(\mathrm{r}+\mathrm{p}-2 \mathrm{rp})($ Jacobs 1974), where $\mathrm{r}$ was the proportion of observations in a specific cover type, and $\mathrm{p}$ the proportion of that vegetative type available. Dhb values from -1 to 0 indicated a cover type used in lower proportion then available, while values from 0 to 1 indicated a cover type used in greater proportion then available. Expected (from the vegetation analysis) and observed non-den (nighttime) locations were used to perform a chi-squared goodness of fit test.

Opossum dens or nesting sites were found in tree cavities in living fence rows or leaf nests in spruce windbreaks were located using radiotelemetry equipment to approach within meters of the inactive animal.

\section{RESULTS}

One male and two females opossums were captured and radiotracked (Table 1). Cheek coloration and pattern identified individuals as D. marsupialis and not D. virginiana (Gardner 1973). 
TABLE 1

Physical characteristics, habitat use and den use of Didelphis marsupialis in Concepción de San Rafael, Heredia, Costa Rica

$\begin{array}{llll}\text { Female } 270 & \text { Female } 412 & \text { Male } 462 & \text { Total }\end{array}$

Physical characteristics

Total length $(\mathrm{cm})$

Weight $(\mathrm{kg})$

Capture date

Frequency

Notes

Home range(ha)(den and non-den)

$$
\text { rt fixes }(\mathrm{n}=)
$$

95\% home range $(\mathrm{h})$

$100 \%$ home range $(\mathrm{h})$

Dens

$\mathrm{n}=$

living fence rows

windbreaks

aband. coffee

76
1.7
$1-21-83$
216.270
8 young
in pouch

\section{2}

3.4

4.8

\section{8}

6

12

$$
\begin{aligned}
& 77 \\
& 2.2 \\
& 1-22-83 \\
& 216.412 \\
& 9 \text { young } \\
& \text { in pouch }
\end{aligned}
$$

\section{5}

2.1

1-23-83

216.462

played dead for $5 \mathrm{~min}$

on release

Total 
estimates of nightly travel came from many fixes at short time intervals. Female \#270 moved an average $941 \mathrm{~m}$ (1255 m, $778 \mathrm{~m}, 752 \mathrm{~m}$ with 18, 17, 16 fixes respectively) while female \#412 moved an average $1004 \mathrm{~m}(1215 \mathrm{~m}, 992 \mathrm{~m}$, $844 \mathrm{~m}, 967 \mathrm{~m}$ with 17, 11, 16, and 15 fixes respectively). Male \#462 traveled 967 m (15 fixes) during one night at a maximum rate of $205 \mathrm{~m}$ and $289 \mathrm{~m}$ between hourly readings. Most movement during this study was in trees, except for forages to garbage dumps. Nocturnal and arboreal activity and daytime denning probably helped opossums to avoid most interactions with local predators (men and dogs), though several other opossums were found dead, apparently killed by dogs in the study area before the study took place. Sunquist et al. (1987) found both sexes averaged about $1 \mathrm{~km}$ per night and males traveled much further, just as in our study.

A total of 260 nocturnal radio telemetry readings were used to estimate home range, all triangulations during the study for the two females and 42 days for male \#462 (Table 1). Between March 1 and April 10 (42 days), male \#462 occupied a 7.5 ha $100 \%$ home range $(5.7$ ha $95 \%$ home range), overlapping about $85 \%$ of both females home ranges (Table 1). However on April 11 , he moved $340 \mathrm{~m}$ south. During the next 14 days, he traveled $1020 \mathrm{~m}$ south of the original home range, using four different nests and nightly foraging areas between 10.9-28.6 ha. Total male \#462 home range for the 63-day study period was 46.5 ha. Sunquist et al. (1987) found male home ranges to be over 10 times those of females (122.7 ha vs 11.3 ha) during the dry season. Both O'Connell (1979) and August (1984) had similar, yet lower density estimates while working on the same ranch Sunquist et al. (1987) did. Reported Virginia opossum home ranges vary between 4.7 ha (Lay 1942) and 254 ha (Fitch and Shirer 1970), but was dependent on how data was taken (radio telemetry $>$ trapping)(Allen et al. 1985, Fitch and Shirer 1970, Gillette 1980). Gillette (1980) and Allen et al. (1985) also found D. virginiana males occupying larger home ranges than females. Gardner (1982) found D. virginiana to be non-territorial, concluding that frequent male dispersal and nomadism ensured mating with receptive females. This was observed in the present study, but not by Sunquist et al. (1987).

Habitat use was compared to habitat availability based on $100 \%$ home range size and 206 non-den localizations. Den sites were not analyzed because living fence rows (31) and windbreaks (17) were highly selected for in 48 of 50 den sites. Opossums utilized cover types in proportions different than their availability in these home ranges $\left(\mathrm{x}^{2}=114.93, \mathrm{df}=6, \mathrm{P}<\right.$ $0.001)$ (Table 2). The habitat use index showed living fence rows and spruce windbreaks used in a greater proportion than available; and pastures and crops used in a lower proportion than available (Table 2). Abandoned coffee and plantations/old fields were used in the same proportion as available while roads were less used then available, but this was not significant (Table 2). Analyzing habitat utilization vs. availability for each opossum individually showed similar trends in the present study. Sunquist et al. (1987) worked in an open grassland habitat with scattered palms and low stature forest being dominant habitats, but did not analyze habitat use. In Missouri, Reynolds (1945) found D. virginiana opossums favored mixed-age-class wooded areas near small streams in habitats that included cultivated areas, pasture, prairie and woodland. Meier (1983) studied urban D. virginiana during an 8-month period in Corvallis, Oregon, USA and found some survived within one city block. Thus, the opossum can exploit many distinct environments.

Fifty diurnal den site locations were found during the study period. In spruce windbreaks, opossum use of squirrels' nests was distinguished by plastic bags hanging around the nest and probably acquired in garbage dumps. Also four opossum nests/dens used for a total of 27 nights were found $10 \mathrm{~m}$ or less from houses. Perhaps the species prefers nests/dens near or in human dwellings (rafters in houses, barns or garages) because they offer security from some predators, are close to food/water sources, allow the animal to observe humans and calculate best 
TABLE 2

Percentages of non-den cover types available and used in three Didelphis marsupialis combined home ranges (100\% minimum convex polygon), Concepción de San Rafael de Heredia, Costa Rica. February-April, 1983

\begin{tabular}{|c|c|c|c|c|c|}
\hline \multirow[b]{2}{*}{ Cover type } & \multirow{2}{*}{$\begin{array}{c}\text { Available in } \\
\text { home ranges } \\
\%\end{array}$} & \multicolumn{2}{|c|}{$\begin{array}{l}\text { Used in home } \\
\text { ranges (non-dens) }\end{array}$} & \multicolumn{2}{|c|}{$\begin{array}{l}\text { Jacobs habitat } \\
\text { index }\end{array}$} \\
\hline & & $\mathrm{N}$ & $\%$ & $\mathrm{D}_{\mathrm{hb}}$ & $x^{2}$ \\
\hline Pasture & 0.32 & 20 & 0.08 & -0.61 & $31.96 \mathrm{sig}$ \\
\hline Abandoned Coffee & 0.10 & 19 & 0.08 & -0.06 & $0.12 \mathrm{~ns}$ \\
\hline $\begin{array}{l}\text { Plantations/orchard/ } \\
\text { abandoned field }\end{array}$ & 0.10 & 22 & 0.08 & +0.05 & $0.09 \mathrm{~ns}$ \\
\hline Living fence rows & 0.20 & 71 & 0.42 & +0.29 & $21.55 \mathrm{sig}$ \\
\hline Spruce windbreaks & 0.15 & 68 & 0.34 & +0.43 & $44.55 \mathrm{sig}$ \\
\hline Road & 0.05 & 3 & 0.01 & -0.42 & $5.17 \mathrm{~ns}$ \\
\hline Crops & $\underline{0.08}$ & $\underline{3}$ & $\underline{0.01}$ & -0.60 & $\underline{11.05 \mathrm{sig}}$ \\
\hline Total & 1.00 & 206 & 1.02 & & 114.49 \\
\hline
\end{tabular}

feeding times. Sunquist et al. (1985) documented D. marsupialis dens during the dry season to be divided almost equally between palm/fig trees, tree cavities and underground $(\mathrm{n}=94)$. Working in a Kansas reserve, Shirer and Fitch (1970) and Reynolds (1945) found most dens in underground cavities of limestone outcrops, while for urban opossums, Meier (1983) found dens in man-made structures in residential neighborhoods. Except in the case of underground dens, these dens were similar to those found in this study.

Throughout their distribution, Didelphis opossums adjusts to a variety of climates, vegetation types and foods. In this study, during the late dry season, D. marsupialis utilized windbreaks and living fence rows as nightly transit routes, spending days sleeping in nests/dens in trees. Apparently they received water from troughs, food or water tanks, because streams were non-existent in the study area during the late dry season. In all probability during the late dry season in lower montane agricultural areas in Central America, existence of living fencerows, windbreaks and human dwellings is an indicator that Didelphis will be present. Pastures and crops were unimportant during the late dry season in determining D. mar- supialis presence and abandoned coffee plantations and tree crops were used according to their availability. Probably, vegetation types with agricultural crops, coffee plantations and orchards would have been utilized more if they had provided food. We recommend a longterm study on different aspects of opossum natural history to clarify that reported here for only dry season trends with few study animals.

\section{ACKNOWLEDGMENTS}

This manuscript was completed while the senior author was on sabbatical leave at the Institute for Environmental Studies (IES), University of Wisconsin-Madison. Thanks are given to Thomas Yuill, director of IES for hosting CSV.

\section{REFERENCES}

Allen, C. H., R. L. Marchinton \& W. M. Lentz. 1985. Movement, habitat use and denning of opossums in the Georgia Piedmont. Amer. Midland Nat. 113:408-412.

Austad, S. N. 1988. The adaptable opossum. Sci. Am. 258:98-104. 
August, P. V. 1984. Population ecology of small mammals in the llanos of Venezuela. Spec. Publ. Mus. Texas Tech Univ. 22:71-104.

Brown, J. L. \& G. H. Orians. 1970. Spacing patterns in mobile animals. Ann. Rev. Ecol. Syst. 1:239-262.

Fitch, H. S. \& H. W. Shirer. 1970. A radio telemetric study of spatial relationships in the opossum. Am. Midl. Nat. 48:170-186.

Gardner, A. 1973. The systematics of the genus Didelphis (Marsupialis: Didelphidae) in North and Middle America. Spec. Publ. Mus., Texas Tech Univ. 4:1-81.

Gardner, A. 1982. Virginia opossum. P. 3-36. In J. A. Chapman \& G. A. Feldhamer (eds.). Wild mammals of North America. Johns Hopkins University, Baltimore, Maryland.

Gillette, L. 1980. Movement patterns of radio-tagged opossums in Wisconsin. Amer. Midland Nat. 104:1-12.

Hayne, D. W. 1949. Calculations of size of home range. J. Mammal. 30:1-18.

Anonymous. 1975. Catastro de las series de precipitaciones medidas en Costa Rica. Instituto Costarricense de Electricidad, San Jose, Costa Rica. 445 p.

Jacobs, J. 1974. Quantitative measurement of food selection. Oecologia 14:413-417.

Knight, M.H., A.K. Knight \& J.J. Bornman. 1988. The importance of borehole water and lick sites to Kalahari ungulates. J. Arid Env. 15:269-281.

Lay, D.W. 1942. Ecology of the opossum in eastern Texas. J. Mamm. 23:147-159.
McManus, J. J. 1971. Activity of captive Didelphis marsupialis. J. Mamm. 52:846-848.

Meier, K. 1983. Habitat use by opossums in an urban environment. M.S. thesis. Oregon State University, Corvallis, Oregon. 69 pp.

Mohr, C. O. 1947. Table of equivalent populations of North American small animals. Am. Midland Nat. 37:223-249.

O’Connell, M.A. 1979. Ecology of Didelphis marsupials from northern Venezuela. P. 73-87. In J. F. Eisenberg (ed.). Vertebrates in the northern neotropics. Smithsonian Institution, Washington, D. C.

Reynolds, H. C. 1945. Some aspects of the life history and ecology of the opossum in Central Missouri. J. Mamm. 26:361-379.

Shirer, H. W. \& H. C. Fitch. 1970. Comparison from radiotracking of movements and denning habits of the raccoon, striped skunk and opossum in northeastern Kansas. J. Mamm. 51:491-503.

Sunquist, M. E., S. N. Austad \& F. Sunquist. 1987. Movement patterns and home range in the common opossum (Didelphis marsupialis). J. Mamm. 68:173-176.

Tosi, J. 1969. Life zone ecology. Tropical Science Center, San Jose, Costa Rica. Map (1:1.000.000 scale).

Tyndale-Biscoe, C. H. \& R. B. MacKenzie. 1976. Reproduction in Didelphis marsupialis and D. albiventris in Colombia. J. Mamm. 57:249265.

Wiseman, G. \& G. Hendrickson. 1950. Notes on the life history and ecology of the opossum in southeast Io- 